\title{
Soil Test Crop Response Based Phosphorus Calibration Study for Bread Wheat in Shashemene District of West Arsi Zone, Oromia, Ethiopia
}

\author{
By: Kasahun Kitila* Abay Chala Mekonnen Workina \\ Oromia Agricultural Research institute, Adami Tulu Agricultural Research Center
}

\begin{abstract}
Soil test based crop response phosphorous calibration study was conducted Shashemene district on bread Wheat crop during the main cropping season of 2018 -2020 with the objectives to determine Pc and Pf for bread wheat crop, and to establish site-specific soil test based phosphorus fertilizer recommendation. RCBD design was used with 3 replication using 5 rates of $\mathrm{N}(0,46,69$ and $92 \mathrm{~kg}$ ha-1) and 5 rates of $\mathrm{P}(0,10,20,30$ and $40 \mathrm{Kg}$ ha- 1$)$ in a factorial combination to determine optimum level of $\mathrm{N}$ - rate for bread wheat crop production. In the second and third year 5 levels of $\mathrm{P}(0,10,20,30$, and $40 \mathrm{Kg}$ ha-1) and $46 \mathrm{~kg} \mathrm{~N}$ hal of optimum nitrogen rate obtained were applied uniformly for all plots to determine P-critical value $(\mathrm{Pc})$ and P-requirement factor $(\mathrm{Pf})$ for bread Wheat. A total of experimental plot size $3 \mathrm{~m} * 3 \mathrm{~m}\left(9 \mathrm{~m}^{2}\right)$ and Seeds rate of $150 \mathrm{~kg}$ ha -1 . Composite Surface soil samples from 0-20 cm depth were collected from each experimental plot before planting. Similarly, after 21 days of planting, composite soil samples were taken at $(0-20 \mathrm{~cm}$ depth) using auger from each plot for analysis of available $\mathrm{p}$ using Olsen method. The result of the study showed that low to extremely high available P ranged from 7.7-56ppm. The mean maximum grain yield (5358kg/ha) was obtained from the application of $46 \mathrm{~kg} \mathrm{~N} / \mathrm{ha}$ and $92 \mathrm{~kg} \mathrm{P} 2 \mathrm{O} 5 /$ ha whereas the lowest $(1873 \mathrm{~kg} / \mathrm{ha})$ was obtained from control treatment. On the other hand, the combination of $69 \mathrm{~kg} \mathrm{~N} / \mathrm{ha}$ and $92 \mathrm{~kg}$ P2o5/ha could result the highest net benefit of 114425.00 birr per hectare. However, $46 \mathrm{~N} \mathrm{~kg}$ ha-1 $\mathrm{N}$ fertilizers was determined as economically feasible optimum $\mathrm{N}$ rates at $2655 \%$, MRR on Eutric andosol in Shashemene district for Bread wheat. From phosphorous calibration study, Pcritical value $(21 \mathrm{ppm})$ and P-requirement factor (4.43) was determined for phosphorus fertilizer recommendation for bread wheat crop production in the area. Therefore, the obtained result has to be verified and the economic benefit must be studied across farmers' fields.
\end{abstract}

Keywords: Calibration, Phosphorous, Soil Test, West Arsi, Bread wheat

DOI: $10.7176 / \mathrm{JBAH} / 11-10-01$

Publication date:May $31^{\text {st }} 2021$

\section{Introduction}

The population of Ethiopia is currently growing at a faster rate and demands an increased proportion of agricultural products. On the other hand, growth in food production is not in equal footings with population pressure. Strengthening food production capability of the country by wisely exploiting its existing human and natural resources is critical option to avert the existing situation. Ethiopia is one of the sub-Saharan African countries where severe soil nutrient depletion restrains agricultural crop production and economic growth. The annual per-hectare net loss of nutrients is estimated to be at least $40 \mathrm{~kg} \mathrm{~N}, 6.6 \mathrm{~kg} \mathrm{P}$ and $33.2 \mathrm{~kg} \mathrm{~K}$ (Scoones and Toulmin, 2004). Continuous cropping, high proportions of cereals in the cropping system, and the application of suboptimal levels of mineral fertilizers aggravate the decline in soil fertility (Tanner et al., 2002). The identification of the proper fertilizer mix is beneficial at the macroeconomic level by improving the efficiency of fertilizer procurement and resource allocation. It is generally understood that crop response to fertilizer inevitably declines, if nutrient applications are continually unbalanced. But, if harvested nutrients are replaced, intensive agricultural systems can be sustained indefinitely, provided that measures are taken to halt soil erosion and to minimize detrimental changes in soil $\mathrm{pH}$.

Fertilizer use in Ethiopia has focused mainly on the use and application of nitrogen and phosphorous fertilizers in the form of NPS and urea for almost all cultivated crops for both market and food security purposes for the last several years. Such unbalanced application of plant nutrients may aggravate the depletion of other important nutrient elements in soils such as $\mathrm{K}, \mathrm{Mg}, \mathrm{Ca}, \mathrm{S}$ and micro-nutrients. Though, nitrogen, phosphorus and potassium are the three major nutrient elements required in large quantities for normal growth and development of crops, some nutrient elements such as potassium are not being used as a commercial fertilizer for agricultural crop production under Ethiopian conditions (Abiye et al., 2004; Asgelil et al., 2007).

Nitrogen and phosphorus are the most yield limiting nutrients in Ethiopia. The use of chemical fertilizer to overcome these nutrient deficiencies is a practice that is receiving a wide acceptance in the country. Some attempts were made in the past to relate soil test data to crop performance and yields but were not successful mainly due to inappropriate design used, inadequate sampling intensity and high level of variability in soil test data (Holetta Genet progress report, 1973/74 and 1975/76). Soil test based fertilizer recommendation plays a 
vital role in ensuring balanced nutrition to crops. Sound soil test calibration is essential for successful fertilizer program and crop production. It is essential that the results of soil tests could be calibrated or correlated against crop responses from applications of plant nutrients in question as it is the ultimate measure of a fertilization program. An accurate soil test interpretation requires knowledge of the relationship between the amount of a nutrient extracted by a given soil test and the amount of plant nutrients that should be added to achieve optimum yield for each crop. Calibrations are specific for each crop type and they may also differ by soil type, climate, and the crop variety (Alem et al., 2008; Fufa and Hassen 2005).

Therefore, fertilizer application schedules should be based on the magnitude of crop response to applied nutrients at different soil fertility levels (Wassie et al., 2011). Like other regions of the country, a fertilizer recommendation for wheat in shashemene district is also not based on soil test results.

1. Therefore, the objective of this study was:

a) To determine Phosphorous critical level and phosphorous requirement factor for wheat in Shashemene district.

b) To determine economically optimum level; of nitrogen fertilizer for wheat production in the study area

\section{MATERIAL AND METHODS}

\subsection{Site description}

The project was conducted in, Shashemene districts of West Arsi Zone, Ethiopia. Shashemene districts are located at $38^{\circ} 56^{\prime} \mathrm{N}, 7^{\circ} 23^{\prime} \mathrm{E}$, and average altitude of $2002 \mathrm{~m}$.a.s.l. The rainfall pattern of the district is characterized by bimodal distribution with small rainy season belg (March-June) and main rainy seasons Meher (July-November). The annual total rainfall is $1520 \mathrm{~mm}$ mean annual average temperature of 19.7.

As far as soil type is concerned, the dominant soil unit of Shashemene district is andosol. Texturally, the soils of the area are classified as sandy loam. Wheat, Barley, potato, maize and teff are the major crops produced in this district.

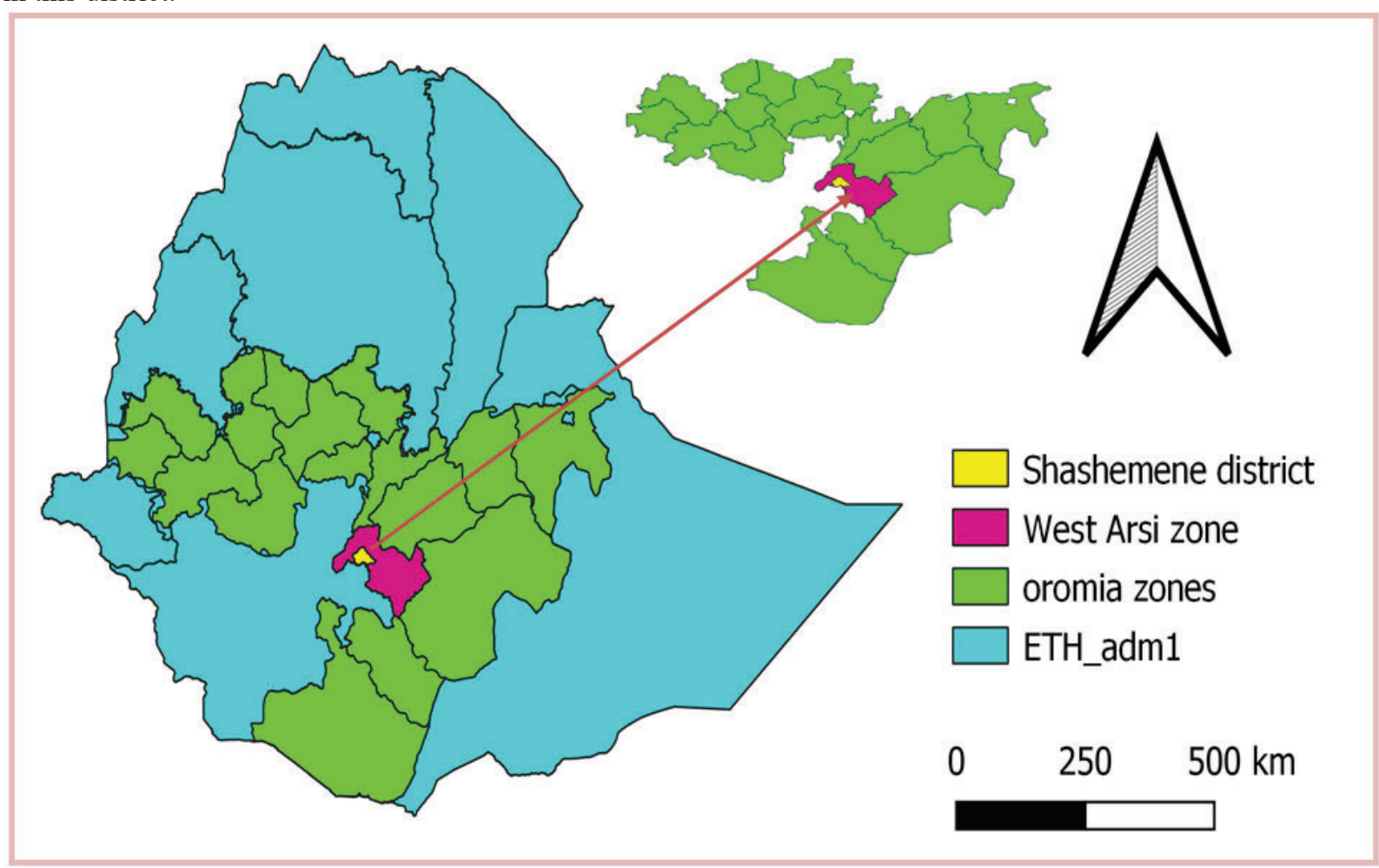

Map1: Location of Shashemene district in West Arsi Zone, Oromia

\subsection{Site selection}

Potentially wheat growing areas in the district was selected with the collaboration of office of agriculture and natural resources of Shashemene district. Composite soil samples were collected from the selected area to analyze total soil $\mathrm{pH}$, Nitrogen and phosphorous. Based on the result of analysis, the sites were classified in to low; medium and high level of available phosphorous.

\subsection{Treatments and Experimental design}

The study was conducted at three purposively selected areas or PA depending on their potential for wheat 
production. In the first year, the study was conducted at six farmers' field to determine economically optimum level of Nitrogen in the district. Accordingly, four level of $\mathrm{N}\left(0,46,69\right.$ and $\left.92 \mathrm{~kg} \mathrm{ha}^{1-}\right)$ and four level of $\mathrm{P}(0,20$, 30 , and $40 \mathrm{Kg} \mathrm{ha}^{-1}$ ) were factorial combined having three replications. In the second year, a basal dressing of nitrogen was given to all plots.

The P-calibration experiment was conducted at ten and eleven farmers' field in the second and third years respectively. Experimental plot size was $3 \mathrm{~m}^{*} 3 \mathrm{~m}$ for each treatment. Treatments were five levels of P $(0,10,20$, 30 and 40 and $\mathrm{Kg} \mathrm{ha}^{-1}$ ) and optimum amount of $\mathrm{N}$-fertilizer applied uniformly for all plots.

The experiment was laid out in randomized complete block design (RCBD) with three replications. Representative composite soil samples were collected from each farmer's field before planting to the depth of 0 $20 \mathrm{~cm}$ for physio-chemical analysis. The recently introduced improved wheat variety (Ogolcho) was used for the trial. After21 days of planting, intensive composite soil samples were collected from each plot to analyze the available phosphorous.

Table 1: Treatment Combinations for determination of optimum Nitrogen

Treatments $(\mathrm{N}, \mathrm{P})$ levels

\begin{tabular}{|l|l|l|l|l|}
\hline$(0,0)$ & $(0,10)$ & $(0,20)$ & $(0,30)$ & $(0,40)$ \\
\hline$(46,0)$ & $(46,10)$ & $(46,20)$ & $(46,30)$ & $(46,40)$ \\
\hline$(69,0)$ & $(69,10)$ & $(69,20)$ & $(69,30)$ & $(69,40)$ \\
\hline$(92,0)$ & $(92,10)$ & $(92,20)$ & $(92,30)$ & $(92,40)$ \\
\hline
\end{tabular}

Table 2: Treatments for determination of P-critical and P-requirement factor

\begin{tabular}{|l|l|l|l|}
\hline Treatments & Optimum N (kg/ha) & Level P kg/ha & Source of fertilizer \\
\hline T1 & 46 & 0 & UREA \\
\hline T2 & 46 & 10 & UREA and TSP \\
\hline T3 & 46 & 20 & UREA and TSP \\
\hline T4 & 46 & 30 & UREA and TSP \\
\hline T5 & 46 & 40 & UREA and TSP \\
\hline
\end{tabular}

\subsection{Data collection}

Physiochemical properties, such as $\mathrm{pH}$, available phosphorous, EC, Total nitrogen and soil texture were analyzed. In addition, yield data was collected and recorded.

\subsection{Soil sample collection and analysis}

Composite soil samples for laboratory chemical and physical characterization was collected at $0-20 \mathrm{~cm}$ depth from each field initially before fertilizer application. Composite samples were also collected three weeks after planting for the determination of available phosphorus and analyzed using Olsen method.

\subsection{Determination of critical $P$ concentration}

Critical value for soil Phosphorus was determined from the relationship between relative yields (yield /maximum yieldx100) and P-soil test values. Critical value is the value below which there is P response and above which there is no $\mathrm{P}$-response. Critical $\mathrm{P}$ value was determined following the Cate-Nelson graphical method where soil $\mathrm{P}$ values (available $\mathrm{p}$ after 3 weeks of application extracted using Olsen method) were put on the $\mathrm{X}$-axis and the relative yield values on the $\mathrm{Y}$-axis. The Cate-Nelson graphical method is based on dividing the Y-X scatter diagram into four quadrants and maximizing the number of points in the positive quadrants while minimizing the number of points in the negative quadrants (Nelson and Anderson, 1977). Percentage yield values were obtained for a wide range of locations where results of fertilizer rate studies are available.

$$
\text { Relative yield } \%=\frac{\text { Yield }}{\text { MaximumYield }} * 100
$$

\subsection{Determination of $P$ requirement factor}

Phosphorus requirement factor is the amount of $\mathrm{P}$ in $\mathrm{kg}$ needed to raise the soil $\mathrm{P}$ by $1 \mathrm{ppm}$. Phosphorus requirement enables to determine the quantity of $\mathrm{P}$ required per hectare to raise the soil test by $1 \mathrm{ppm}$, and to determine the amount of fertilizer required per hectare to bring the level of available $\mathrm{P}$ above the critical level.

Phosphorus requirement factor $=\frac{k g P \text { applied }}{\Delta \text { soil } P}$

Finally, Rate of $P$ fertilizer to be applied $=($ Critical $P$ conc. - initial $P$ values $) \times P$ requirement factor 


\subsection{Data management and Analysis}

All agronomic and soil data which will be collected across locations will be properly managed using the EXCEL computer software. The collected data was subjected to the analysis of variance using the SAS/STAT computer package version 9.0 (SAS Institute, 2001). Statistical (Minitab-19) was used to develop graphs and correlation analysis

\subsection{Economic Analysis}

Economic analysis was performed to investigate the economic feasibility of the treatments. Partial budget and MRR (\%) analyses were used to determine the economic analysis (CIMMT, 1988). The average open market price $\left(\right.$ Birr kg ${ }^{-1}$ ) for different crops and the official prices of $\mathrm{N}, \mathrm{P}$ and $\mathrm{K}$ fertilizers were used for analysis.

Marginal rate of return (MRR) was calculated using the formula given blow.

\section{MRR $=\underline{\text { Net Income From Fertilized Field }- \text { Net Income From Unfertilized Field }}$ Total Variable Cost From Fertilizer Application}

Total variable cost is a cost incurred due to application of $\mathrm{P}$ fertilizer (both but in separate of Soil test based $\mathrm{P}$ calibration result and farmers' fertilizer rate) with the assumption that the rest of the costs incurred are the same for all treatments.

Gross income is obtained by multiplying mean grain yield $(\mathrm{kg} / \mathrm{ha})$ of each treatment by the price of one $\mathrm{kg}$ of the grain. Net income is calculated by subtracting the total variable cost from the gross income.

\section{Result and Discussion}

\subsection{Soil physiochemical characteristics of the study sites}

Composite soil samples were collected from each experimental site to characterize the physiochemical properties. The following (table1) showed the soil laboratory analysis to determine the physical and chemical properties of the sites before planting. Soil PH. Soil organic carbon, electrical conductivity (EC), total nitrogen (TN), initial soil phosphorous (pi) and soil texture were analysed.

3.1.1 Soil pH: soil $\mathrm{pH}$ is an indicator of soil acidity or alkalinity level. Accordingly, the average pH levels of the study sites were 6.71 which is in the acceptable range for optimum crop production (table1). The level $\mathrm{pH}$ usually affects the availability of major crop nutrients. The desirable soil $\mathrm{pH}$ range for optimum plant growth varies among crops. Generally, soil $\mathrm{pH}$ 6.0-7.5 is recommended for most plants as most nutrients become available in this pH range (US Environmental Protection Agency, 2004).

Table1: Soil physiochemical properties of experimental sites before application

\begin{tabular}{|c|c|c|c|c|c|c|c|}
\hline \multirow[t]{2}{*}{ Sites } & \multicolumn{7}{|c|}{ Soil properties } \\
\hline & Soil pH & $\begin{array}{l}\text { Initial Ava.P } \\
\text { in ppm }\end{array}$ & $\begin{array}{l}\text { SOC } \\
(\%)\end{array}$ & $\begin{array}{l}\text { Total N } \\
(\%)\end{array}$ & $\begin{array}{l}\text { EC } \\
\text { mmhoms/cm }\end{array}$ & $\mathrm{C}: \mathrm{N}$ & Soil texture \\
\hline 1. & 6.50 & 7.72 & 3.66 & 0.14 & 0.19 & 26.14 & Sandy Loam \\
\hline 2. & 5.98 & 10.00 & 2.83 & 0.17 & 0.57 & 16.65 & Sandy Loam \\
\hline 3. & 6.50 & 7.40 & 2.66 & 0.15 & 0.18 & 17.73 & Sandy Loam \\
\hline 4. & 7.20 & 31.00 & 2.37 & 0.14 & 0.13 & 16.93 & Sandy Loam \\
\hline 5. & 6.75 & 13.18 & 2.82 & 0.17 & 0.23 & 16.59 & Sandy Loam \\
\hline 6. & 7.35 & 18.82 & 2.96 & 0.18 & 0.19 & 16.44 & Sandy Loam \\
\hline 7. & 7.12 & 20.76 & 2.83 & 0.15 & 0.20 & 18.87 & Sandy Loam \\
\hline 8. & 6.50 & 11.20 & 2.66 & 0.22 & 0.21 & 12.09 & Sandy Loam \\
\hline 9. & 6.50 & 15.04 & 2.83 & 0.14 & 0.19 & 20.21 & Sandy Loam \\
\hline 10. & 5.98 & 14.12 & 2.98 & 0.17 & 0.57 & 17.53 & Sandy Loam \\
\hline 11. & 6.50 & 19.96 & 2.68 & 0.15 & 0.18 & 17.87 & Sandy Loam \\
\hline 12. & 7.20 & 12.28 & 2.37 & 0.14 & 0.13 & 16.93 & Sandy Loam \\
\hline 13. & 6.75 & 13.32 & 2.82 & 0.17 & 0.23 & 16.59 & Sandy Loam \\
\hline 14. & 7.35 & 18.88 & 2.96 & 0.18 & 0.19 & 16.44 & Sandy Loam \\
\hline 15. & 7.12 & 20.24 & 2.83 & 0.15 & 0.20 & 18.87 & Sandy Loam \\
\hline 16. & 6.50 & 17.84 & 3.16 & 0.22 & 0.21 & 14.36 & Sandy Loam \\
\hline 17. & 6.78 & 14.22 & 3.71 & 0.25 & 0.23 & 14.84 & Sandy Loam \\
\hline 18. & 6.40 & 10.56 & 3.66 & 0.22 & 0.21 & 16.64 & Sandy Loam \\
\hline 19. & 6.90 & 15.04 & 2.99 & 0.18 & 0.19 & 16.61 & Sandy Loam \\
\hline 20. & 6.50 & 7.72 & 2.79 & 0.14 & 0.19 & 19.93 & Sandy Loam \\
\hline Mean & 6.71 & 14.96 & 2.92 & 0.17 & 0.23 & 17.41 & \\
\hline
\end{tabular}


3.1.2 Soil Organic carbon: Soil organic carbon is a measureable component of soil organic matter. It is an indicator of the potential of soil nutrient retention and turnover, soil structure, moisture retention and carbon sequestration. As it is indicated in table 1, the average SOC of the study site was $2.92 \%$. The study by Emanuel et,al, 2018 also showed that soil organic carbon on agricultural land varies from $1.34-9.75 \%$ depending on its degree of degradation and land management.

3.1.3 Total Nitrogen: Total Nitrogen (Tot N) exists in organic forms and inorganic (or mineral) forms such as plant available ammonium (NH4 +) and nitrate (NO3 -). It was identified that soil total nitrogen content of the study area was $0.17 \%$ which is found to be classified as low (table 1 ). The majority of Tot $\mathrm{N}$ is bound in soil organic matter. Soil microorganisms decompose organic matter to liberate energy stored in chemical bonds to fuel their activity and to harvest carbon and nitrogen to build their biomass. Soil biota requires nitrogen for the synthesis of their proteins and other nitrogen containing organic molecules. As dynamic microbial populations grow, if there is insufficient nitrogen in the organic matter they are decomposing they can out-compete crop plants for inorganic nitrogen. This is called immobilization. Conversely, if the organic matter contains sufficient nitrogen to satisfy microbial demands, excess inorganic $\mathrm{N}$ is released to crop plants (Harold van, et.al, 2020)

\subsubsection{Soil available phosphorous}

Next to nitrogen, phosphorus is often the limiting nutrient for crop production in tropical soils. In soil phosphorus availability studies, the selection of an appropriate methodology is a key factor. In Ethiopia, the Olsen's NaHCO3 method (Olsen et al., 1954) is often used for determining soil available P. Available P contents of most of tropical soils were categorized as very low for available is $p<5 \mathrm{mg} \mathrm{kg}^{-1}$, low for available $\mathrm{p}$ is between 5-9 $\mathrm{mg} \mathrm{kg}^{-1}$,Midium for available $\mathrm{p}$ between $9-17 \mathrm{mg} \mathrm{kg}^{-1}$ and high for available $\mathrm{p}$ between $18-$ $25 \mathrm{mg} \mathrm{kg}^{-1}$ (Cottenie, 1980, FAO Soil Bulletin 38/2, 2012). The average available phosphorous content of the soil in the study area before the application of the treatment were 14.96ppm (Table1). Accordingly, P contents of the soil in the study area were categorized under medium status. Application of phosphorous fertilizer at different rate significantly affect soil available phosphorous $(p<0.05)$. Soil available $p$ was increasing with increased level of application. Available P (Olsen extractable) in the studied sites varied between 18.64 and $32.04 \mathrm{mg} \mathrm{kg}-1$ after 21 days of the treatment application (Table2). Therefore, according to Cottenie, 1980, and FAO Soil Bulletin 38/2, 2012, available p of the site after application of phosphorous fertilizer was increased and categorized to be very high.

This result is also in agreement with the findings of Debele, 2001, Mamo et al. 2004, Negassa and Gebrekidan, 2010 who reported that availability phosphorous to the crop usually affected by the level of soil phosphorous fertilizer applied, soil organic matter content and level of soil pH. They argued that Soils with inherent $\mathrm{pH}$ values between 6 and 7.5 are ideal for P-availability, while $\mathrm{pH}$ values below 5.5 and between 7.5 and 8.5 limits P-availability to plants due to fixation by aluminum, iron, or calcium. Soil PH of the study area was 6.71 (Table 1) which is nearly neutral and ideal level for availability of phosphorous to the crop.

Table2: Available Phosphorous after 21 days of application

\begin{tabular}{|l|l|l|l|l|l|}
\hline Treatment & $\begin{array}{l}\text { Level of P in } \\
\text { ppm/ha applied }\end{array}$ & $\begin{array}{l}\text { Average Available P in } \\
\text { PPM }\end{array}$ & Std dev & Minimum & Maximum \\
\hline 1 & 0 & $14.07^{\mathrm{d}}$ & 4.92 & 5.50 & 28.42 \\
\hline 2 & 23 & $18.64^{\mathrm{c}}$ & 4.32 & 10.00 & 30.68 \\
\hline 3 & 46 & $27.17^{\mathrm{b}}$ & 5.25 & 18.33 & 37.00 \\
\hline 4 & 69 & $29.77^{\mathrm{ab}}$ & 6.92 & 17.00 & 41.00 \\
\hline 5 & 92 & $32.04^{\mathrm{a}}$ & 6.25 & 19.00 & 47.00 \\
\hline $\mathrm{CV}(\%)$ & 15.44 & & & \\
\hline LSD $(0.05)$ & 2.86 & & & \\
\hline
\end{tabular}

\subsection{Economically optimum level of Nitrogen fertilizer}

The maximum grain yield (5358kg/ha) was obtained at the combined application of 46kg/ha $\mathrm{N}$ and $92 \mathrm{~kg} / \mathrm{ha}$ P2O5 while the lowest grain yield $(1873 \mathrm{~kg} / \mathrm{ha})$ was obtained at the control treatment. Similar study by Shaver (2014) indicated that optimum yield can be gained in the presence of all available essential nutrients at balanced and optimum level where phosphorus and nitrogen are the most deficient essential nutrient in the country. The main effect for nitrogen fertilizer significantly $(\mathrm{p}<0.05)$ affected the grain yield. It was significantly vary from $2428 \mathrm{~kg} / \mathrm{ha}$ to $4587 \mathrm{~kg} / \mathrm{ha}$ in applying $46 \mathrm{~kg} \mathrm{~N}$ and $92 \mathrm{kgN}$ respectively (Table 3 )

However, there is no significance differences $(\mathrm{p}<0.05)$ between the combined effects of Nitrogen and phosphorous fertilizers level above $46 \mathrm{~kg} /$ ha on grain yield response. This implies that application of N and P2O5 greater than $46 \mathrm{~kg} /$ ha may not be economically important. On the other hand, the partial economic analysis was conducted to determine economically optimum level of nitrogen fertilizer. Accordingly, maximum net benefit of 114425.00 birr was obtained where $69 \mathrm{~kg} / \mathrm{ha} \mathrm{N}$ was applied. For a treatment to be considered as worthwhile to 
farmers, 100\% marginal rate of return (MRR) was the minimum acceptable rate of return Dejene et al, 2020. Therefore, $46 \mathrm{~N} \mathrm{~kg}$ ha-1 $\mathrm{N}$ fertilizers was determined as economically feasible optimum $\mathrm{N}$ rates at $2655 \%$, MRR on Eutric andosol in Shashemene district for Bread wheat.

Table2: Partial budget analysis using CIMMT, 1988

\begin{tabular}{|l|l|l|l|l|l|l|l|l|l|}
\hline $\begin{array}{l}\text { No } \\
\text { N- }\end{array}$ & $\begin{array}{l}\text { UREA in } \\
\text { levels }\end{array}$ & $\begin{array}{l}\text { Unit } \\
\text { price }\end{array}$ & TVC & $\begin{array}{l}\text { Grain } \\
\text { YLD }\end{array}$ & $\begin{array}{l}\text { Unit } \\
\text { price }\end{array}$ & $\begin{array}{l}\text { Gross } \\
\text { Benefit }\end{array}$ & $\begin{array}{l}\text { Net } \\
\text { Benefit }\end{array}$ & $\begin{array}{l}\text { MRR } \\
(\%)\end{array}$ \\
\hline 1 & 0 & 0 & 15 & 0 & 2297.00 & 25 & 57425 & 57425 & 0 \\
\hline 2 & 46 & 100 & 15 & 1500 & 3950.00 & 25 & 98750 & 97250 & 2655 \\
\hline 3 & 69 & 150 & 15 & 2250 & 4667.00 & 25 & 116675 & 114425 & 2200 \\
\hline 4 & 92 & 200 & 15 & 3000 & 4509.00 & 25 & 112725 & 109725 & 2076 \\
\hline
\end{tabular}

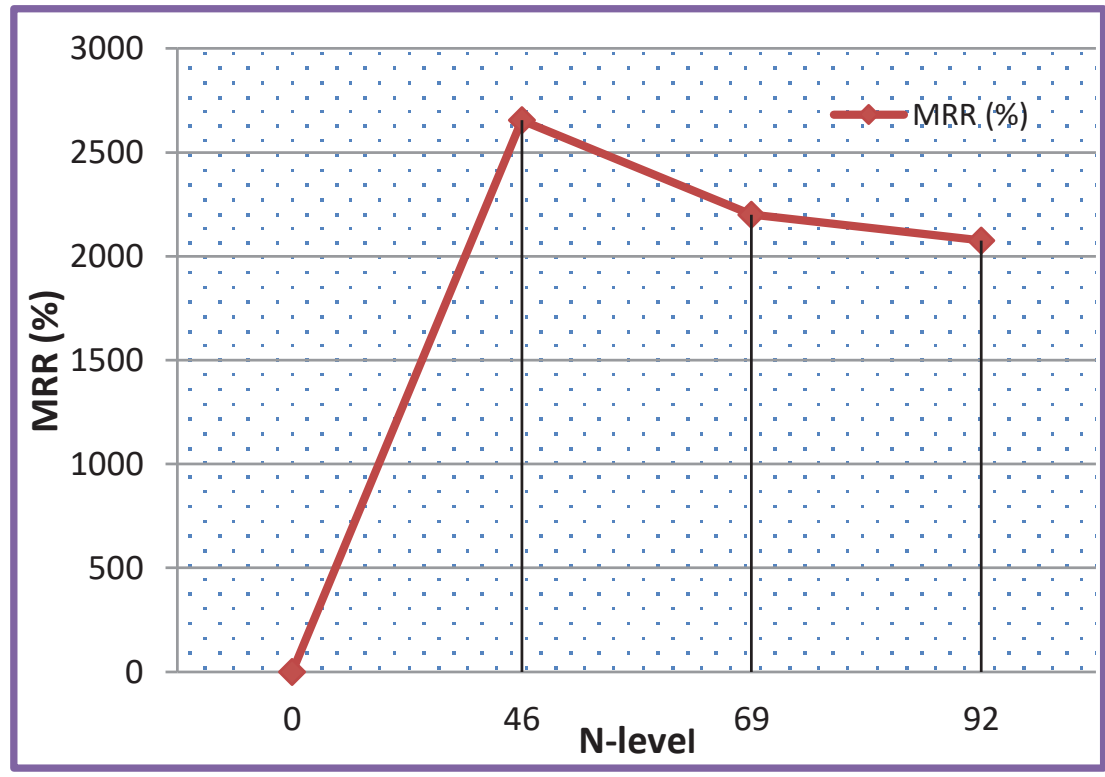

Figure1: The maximum MRR with the optimum N-applied

Table 3: Response of wheat grain yield to NP fertilizers application

\begin{tabular}{|c|c|c|c|c|}
\hline \multirow[t]{2}{*}{ Level of $\mathrm{N}$ in $\mathrm{kg} / \mathrm{ha}$} & \multicolumn{4}{|c|}{ Level of phosphorous(P2O5) in $\mathrm{kg} / \mathrm{ha}$} \\
\hline & 0 & 23 & 46 & 92 \\
\hline 0 & $1873^{\mathrm{g}}$ & $2154^{\mathrm{fg}}$ & $2308^{\mathrm{fg}}$ & $2853^{\text {defg }}$ \\
\hline 46 & $2428^{\mathrm{efg}}$ & $3516^{\text {cdef }}$ & $4498^{\mathrm{abc}}$ & $5358^{a}$ \\
\hline 69 & $3886^{\text {bcde }}$ & $4093^{\text {abcd }}$ & $4600^{\mathrm{abc}}$ & $4891^{\mathrm{abc}}$ \\
\hline 92 & $4587^{\mathrm{abc}}$ & $5106^{\mathrm{ab}}$ & $5319^{a}$ & $4626^{\mathrm{abc}}$ \\
\hline LSD $(5 \%)$ & \multicolumn{4}{|l|}{1466} \\
\hline $\mathrm{CV}$ & \multicolumn{4}{|l|}{12.47} \\
\hline
\end{tabular}

\subsection{Determination of Phosphorus Critical Value}

For the determination of critical values of P, the Cate-Nelson diagram method (Nelson and Anderson, 1977) was used, where soil $\mathrm{P}$ values were put on the $\mathrm{X}$-axis and relative yield values on the $\mathrm{Y}$-axis, and scatter points were divided into two populations. Then, by moving the two perpendicular lines vertically and horizontally, until the number of points showing through the overlay in the two positive quadrants is at a maximum (or conversely, the number of points in the negative quadrants is at a minimum). Finally, the point where the vertical line crosses the $\mathrm{X}$-axis was defined as 'critical soil test $\mathrm{p}$ levels.

The critical P concentration (Pc) was determined from the scatter diagram drawn using relative grain yields of bread wheat and the subsequent soil test $\mathrm{P}$ values. According to the Nelson, $\mathrm{p}$ critical level will be determined for the top $20 \mathrm{~cm}$ of soil using Olsen method. The P critical defined by the Cate Nelson method in this study

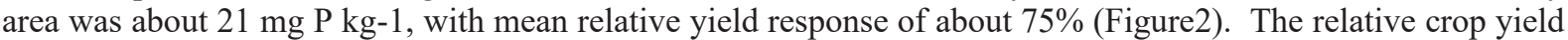
showed a degreasing trend even though the soil test $\mathrm{P}$ value is above the critical. If available $\mathrm{P}$ is increasing beyond this level, the cost of additional $\mathrm{P}$ fertilizer to produce extra yield would likely be greater than the value of the additional yield (Kefyalew A. et al, 2017). These results are in general in accordance with the results of several studies, which showed the positive response of wheat grain yield and other cereals to phosphorous fertilization in Ethiopian highland areas (Admassu, 2017; Agegnehu et al., 2015). Additionally, Admassu (2017) 
also stated the importance of soil test based P fertilizer application for improving yield and yield components of tef and wheat in Ethiopian.

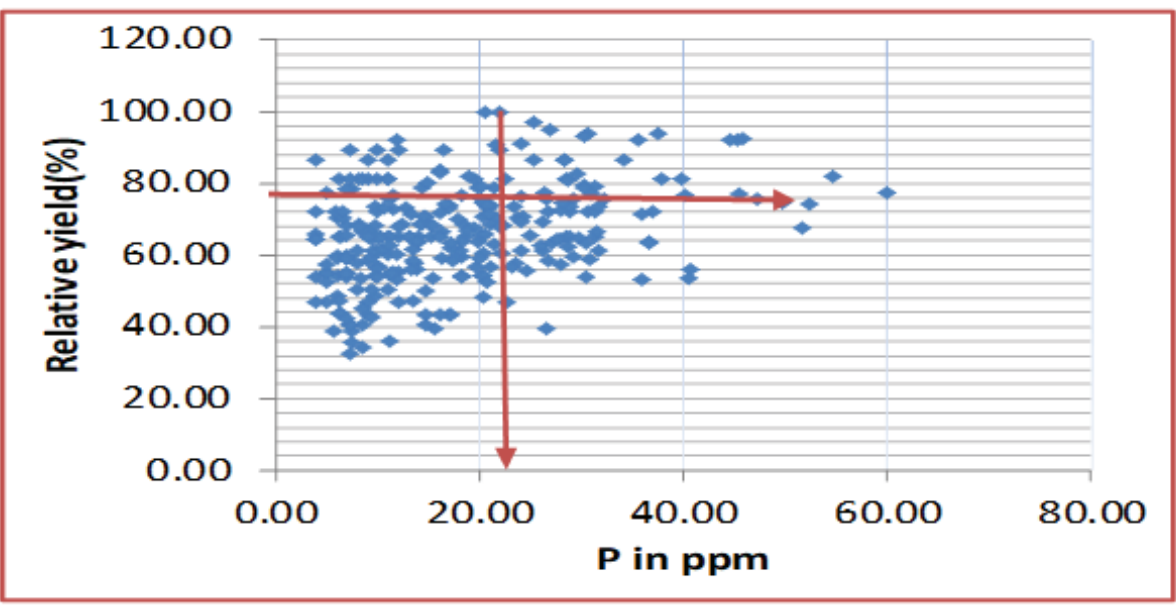

Figure 2: Phosphorus Critical Value as determined by Olsen method

\subsection{Phosphorous requirement factor}

Calculated phosphorus requirement factor $(\mathrm{Pf})$ for bread wheat production on Eutric andosol in Shashemene district was 4.43 (Table4). Phosphorous requirement factor $(\mathrm{Pf})$ is the amount of $\mathrm{P}$ required to raise the soil test $\mathrm{P}$ level by $1 \mathrm{mg} \mathrm{kg}-1$. Thus the rate of $\mathrm{P}$ fertilizer required per hectare can be calculated using the soil critical $\mathrm{P}$ concentration, initial soil $\mathrm{P}$ determined for each site before planting and the $\mathrm{P}$ requirement factor (pf).

Table4: Phosphorous requirement factor for wheat in Shashemene district

\begin{tabular}{|l|l|l|l|l|}
\hline No. & $\begin{array}{l}\text { Phosphorous (P) fertilizer } \\
\text { applied (kg P/ha) }\end{array}$ & $\begin{array}{l}\text { Average soil } \\
\mathbf{P}(\mathbf{p p m})\end{array}$ & $\begin{array}{l}\mathbf{P} \text { - increase over } \\
\text { control }(\Delta \text { soil } \mathbf{P})\end{array}$ & $\begin{array}{l}\text { P- requirement factor } \\
(\mathbf{P r})\end{array}$ \\
\hline 1 & 0 & 18.20 & - & - \\
\hline 2 & 10 & 21.10 & 2.9 & 3.44 \\
\hline 3 & 20 & 23.15 & 4.95 & 4.04 \\
\hline 4 & 30 & 24.25 & 6.02 & 4.98 \\
\hline 5 & 40 & 25.75 & 7.55 & 5.29 \\
\hline \multicolumn{5}{|l|}{ Average } \\
\hline
\end{tabular}

\section{Conclusion and Recommendations}

Chemical fertilizers are one of the most important inputs for maintaining agricultural production and productivity of the country. Adequate and balanced levels of phosphorus (p) and other nutrient are important to get maximum and sustainable production. Therefore, sound soil test calibration is essential for successful fertilizer program and crop production. Phosphorus calibration study has been conducted on bread wheat for two years (2019-2020 growing season) at Shashemene district.

Accordingly, economically optimum nitrogen rate (46 kg N/ha), critical P (Pc) concentrations (21 ppm) and $\mathrm{P}(\mathrm{Pf})$ requirement factors (4.43) for bread wheat was determined for the study area. Farther verification of the result on farmers' field could be a prerequisite before disseminating the technology to the user.

\section{Acknowledgements}

First of all, I would like thank God who enables me to get success in every steps of the research activity. Secondly, the authors would like to thank Oromia Agricultural Research Institute for financial support and Adami Tulu Agricultural Research Center for providing all the necessary facilities required for the research. At last but not at least, our special thank also forwarded to all staff members, especially to the technical assistances: Abdo Oshe, Gebremikael Adera, Qasim Barissa and Jemal Qure for their unreserved effort from land preparation to harvesting and data collections

\section{REFERENCES}

Abiye, A., M. Tekalign, D. Peden, and M. Diedhiou. (2004). Participatory On-Farm Conservation Tillage Trial in Ethiopian Highland Vertisols: The Impact of Potassium Application on Crop Yield. Expl. Agric. 40:369379.

A. Cottenie, "Soil and plant testing as a basis of fertilizer recommendations," FAO Soil Bulletin 38/2, Food and Agriculture Organization of the United Nations, Rome, Italy, 1980.View at: Google Scholar 
Admassu, L. (2017). Soils test phosphorous calibration for Tef [Eragrostis tef (Zucc.) Trotter] production on nitisols of Central Ethiopian Highlands. American-Eurasian Journal of Agricultural \& Environmental Sciences, 17(4), 320-331.

Agegnehu, G., Nelson, P. N., Bird, M. I., \& van Beek, C. (2015). Phosphorus response and fertilizer recommendations for wheat grown on nitisols in the Central Ethiopian Highlands. Communications in Soil Science and Plant Analysis, 46(19), 2411-2424.

Amanuel, W., Yimer, F. \& Karltun, E. Soil organic carbon variation in relation to land use changes: the case of Birr watershed, upper Blue Nile River Basin, Ethiopia. $j$ ecology environ 42, 16 (2018).

Asgelil, D., B. Taye and A. Yesuf. (2007). The status of Micro-nutrients in Nitisols, Vertisols, Cambisols and Fluvisols in major Maize, Wheat, Teff and Citrus growing areas of Ethiopia. In proceedings of Agricultural Research Fund.pp 77-96.

Alem L, Joseph M, Kethers S, Steele C, Wilkin son R. 2008. Information environments for supporting consistent registrar medical handover. HIM J; 37(1): 9-25.

Debele B. Management of Vertisols and catchments treatment on Delanta Dawunt plateau, North Wollo prepared for Oxfam-GB Addis Ababa, May, 2001.

Dejene Getahun, Abraham Feyisa, Lello Dejene, Dereje Girma. 2020. Soil Test Based Crop Response Phosphorus Calibration Study on Bread Wheat in Degem District of North Shewa Zone, Oromia. International Journal of Economy, Energy and Environment. 5(1), 1-5.

Ethiopian Agricultural Research Organization (EARO) 2000. Holetta Agricultural Research Center annual report, 1999. EARO/HRC, Addis Ababa.

Fufa, B., and R.M. Hassan. 2005. Stochastic Technology and Crop Production Risk: The Case of Small-Scale Farmers in East Hararghe Zone of Oromia Regional State in Ethiopia, Strategies and Analysis for Growth and Access. Ethiopia

Harold van Es, Robert Schindelbeck Joseph Amsili and Kirsten KurtzCorne, University Soil Health Laboratory, March 2020

Kefyalew Assefa, Tilahun Firomsa, and Tadesse Hunduma (2017).Phosphorus Critical Level and Optimum Nitrogen Rate Determination on Teff for Sustainable Soil Fertility Management and Economical Teff Production at Lume Area of Oromia Region, Ethiopia. Journal of Biology, Agriculture and Healthcare, No.19, 2017

Mamo T, Haque I, Kamara CS. Phosphorus status of some Ethiopian highland Vertisols. In Management of Vertisols in sub-Saharan Africa. Proceedings of a conference held at International Livestock Centre for Africa (ILCA), 31 August-4 September 2004 Addis Ababa, Ethiopia. p. 232-52

Nelson, L. A. and Anderson, R.L. 1977.Partioning of soil test-crop response probability. Pages 19-38 ir? M. Stelly, ed. Soil testing: Correlating and interpreting the analytical results. Special Publ. no. 29, Am. Soc. Agron., Madison. Wis

Tunner, Hailu G.H, D.G., Mengistu, H. 2002. Wheat research in Ethiopia: a historical perspective. Addis Ababa:IAR/CIMMYT

US Environmental Protection Agency Method 9045D Soil and Waste pH, Revision 4, November 2004

Scoones, I. and C. Toulmin. 1999. Soil nutrient budgets and balances: What use for policy? Managing Africa's Soils No. 6

Shaver, T.M. 2014. "Soil testing and Nutrient recommendations". University of Nebraska. USA.

Wassie Haile and ShiferawBoke. 2011. Response of Irish Potato (Solanumtuberosum) to the Application of Potassium at Acidic Soils of Chencha, Southern Ethiopia. International Journal of Agricultural Biology 13: 595-598 